\title{
NEW GUIDELINES FOR CARDIOPULMONARY RESUSCITATION
}

\author{
Maria Celia Barcellos Dalri ${ }^{1}$ \\ Izilda Esmenia Muglia Araújo ${ }^{2}$ \\ Renata Cristina de Campos Pereira Silveira ${ }^{3}$ \\ Silvia Rita Marin da Silva Canini ${ }^{4}$ \\ Regilene Molina Zacareli Cyrillo ${ }^{5}$
}

Dalri MCB, Araújo IEM, Silveira RCCP, Canini SRMS, Cyrillo RMZ. New guidelines for cardiopulmonary resuscitation. Rev Latino-am Enfermagem 2008 novembro-dezembro; 16(6):1060-2.

Cardiopulmonary arrest (CPA) poses a severe threat to life; cardiopulmonary resuscitation (CPR) represents a challenge for research and assessment by nurses and their team. This study presents the most recent international recommendations for care in case of cardiopulmonary heart arrest, based on the 2005 Guidelines by the American Heart Association (AHA). These CPR guidelines are based on a large-scale review process, organized by the International Liaison Committee on Resuscitation (ILCOR). High-quality basic and advanced CPR maneuvers can save lives.

DESCRIPTORS: nursing; heart arrest; cardiopulmonary resuscitation; emergency nursing

\section{NUEVAS DIRECTRICES PARA LA RESUCITACIÓN CARDIOPULMONAR}

La parada cardiorrespiratoria (PCR) es una ocurrencia que presenta una grave amenaza a la vida; la resucitación cardiopulmonar $(R C P)$ representa un desafío para la investigación y la evaluación por parte del enfermero y su equipo. Este estudio presenta las más recientes recomendaciones internacionales sobre la atención a la parada cardiorrespiratoria, basada en las Directrices de 2005 de la American Heart Asociation (AHA). Esas directrices sobre RCP se fundamentan en un proceso de revisión extenso, organizado por el International Liasion Committee on Resuscitation (ILCOR). Las maniobras básicas y avanzadas de RCP ofrecidas con calidad pueden salvar vidas.

DESCRIPTORES: enfermería; paro cardíaco; resucitación cardiopulmonar; enfermería de urgencia

\section{NOVAS DIRETRIZES DA RESSUSCITAÇÃO CARDIOPULMONAR}

A parada cardiorrespiratória (PCR) é intercorrência de grave ameaça à vida; a ressuscitação cardiopulmonar $(R C P)$ representa desafio para a investigação e a avaliação por parte do enfermeiro e sua equipe. Esse estudo apresenta as mais recentes recomendações internacionais sobre atendimento da parada cardiorrespiratória, baseado nas Diretrizes de 2005 da American Heart Association (AHA). Essas diretrizes sobre RCP fundamentamse num processo de revisão extenso, organizado pelo International Liasion Committee on Resuscitation (ILCOR). As manobras básicas e avançadas de RCP com qualidade podem salvar vidas.

DESCRITORES: enfermagem; parada cardíaca; ressuscitação cardiopulmonar; enfermagem em emergência

\footnotetext{
${ }^{1}$ RN, Faculty, University of Sao Paulo at Ribeirao Preto College of Nursing, WHO Collaborating Centre for Nursing Research Development, Brazil, e-mail: macdalri@eerp.usp.br; ${ }^{2}$ RN, Faculty, Faculty of Medical Sciences, State University of Campinas, e-mail: iema@fcm.unicamp.br; ${ }^{3}$ RN, Doctoral student, University of Sao Paulo at Ribeirao Preto College of Nursing, WHO Collaborating Centre for Nursing Research Development, Brazil, e-mail: recris@eerp.usp.br; ${ }^{4}$ RN, Faculty, University of Sao Paulo at Ribeirao Preto College of Nursing, WHO Collaborating Centre for Nursing Research Development, Brazil, e-mail: canini@eerp.usp.br; ${ }^{5}$ RN, Faculty at Centro Universitário Barão de Mauá, Brazil, Nurse at Municipal Secretary of Health at Ribeirão Preto, Brazil.
} 


\section{INTRODUCTION}

The current guidelines emphasize simplicity in order to make the cardiopulmonary resuscitation procedure easier to remember. The emphasis in this study is to offer the patient, in situation of cardiopulmonary arrest (CPA), a cardiopulmonary resuscitation delivered by a competent professional ${ }^{(1)}$. The author stresses the idea, which we agree with, that resuscitation science has rapidly developed. Fast, safe and efficient professional interventions, aiming to recover spontaneous ventilation and circulation, change the chances of survival ${ }^{(1-2)}$.

\section{CARDIORESPIRATORY ARREST AND CARDIOPULMONARY RESUSCITATION}

In the last 50 years, with the introduction of cardiopulmonary resuscitation (CPR), great progress has been made in cardiology emergency and advanced life support. These interventions have contributed to recover circulation and improve the survival of victims of cardiopulmonary arrest ${ }^{(3-4)}$.

Cardiopulmonary arrest (CPA) is, sometimes, an unexpected intercurrence, which poses a severe threat to life, especially to those who suffer a sudden cardiac arrest (SCA) out of hospital, and many of these patients present ventricular fibrillation (VF). The management of these victims, at any care level, of low or high complexity, needs early CPR and defibrillation ${ }^{(3-5)}$. These maneuvers partially depend on the availability and functionality of resuscitation equipment, which should be ready for immediate use, and also on the team's training, which can be achieved through courses of Basic and Advanced Life Support in Cardiology. A high quality CPR can double or triple the rates of survival after a CPA.

\section{THE NEW GUIDELINES FOR CARDIOPULMONARY RESUSCITATION}

The American Heart Association (AHA), through the International Committee on Resuscitation, carried out a literature review on cardiopulmonary resuscitation. The mission was to identify and review relevant international science and knowledge in CPA and offer a consensus on care delivery guidelines ${ }^{(3-5,7)}$.
The review process for the new guidelines was initiated in 2003, when the International Liasion Committee on Resuscitation (ILCOR) ${ }^{(5)}$ established six topics of interest in CPR: Basic life support; advanced life support; acute coronary syndrome; life support in pediatrics; life support in neonatology, and interdisciplinary action overlapping with topics on education. This committee met in January 2005, during the International Consensus on Emergency Cardiovascular Care and cardiopulmonary Resuscitation Science with Treatment Recommendations Conference $(\text { ICC })^{(7)}$ in Dallas, USA.

The scientific studies and treatment recommendations were published in the International Consensus on Cardiopulmonary Resuscitation and Emergency Cardiovascular Care Science with Treatment Recommendations (CoSTR) ${ }^{(5)}$. Nurses, among others in the health team, educators in the health area (nursing, medicine, dentistry, physiotherapy and physical education schools, among others) and researchers directly or indirectly involved with the topic, whether in care, teaching or research, should read the complete document with the new guidelines, published in the Resuscitation journal, November 2005 and in the Circulation journal, December 2005.

The changes recommended in 2005 aim to simplify the CPR guidelines, eliminating differences in technical procedures and also in the different age ranges; increase the number of thoracic compressions and the quality of uninterrupted compressions. Currently, the recommended compression-ventilation rate is 30:2 in care delivery to victims of all ages (except in newborns), whether one or two first responders are present, until an artificial route (e.g. endotracheal tube) is installed. It is also recommended that the CPR be performed by two first responders in babies and children, using a compression-ventilation rate of $15: 2^{(3-5,7)}$

Efficient thoracic compressions reestablish the blood flow during CPR and the guidelines highlight the following aspects: for the application of efficient thoracic compressions, all first responders should exert "uninterrupted, strong and fast compressions"; compress the thorax at a frequency of approximately 100 compressions per minute, on all victims (except for newborns); allow the thorax to totally return back to normal position after each compression, and use approximately the same time to compress and relax; try to minimize interruptions of thoracic compressions, 
because each time thoracic compressions are interrupted, the blood flow ceases ${ }^{(3)}$.

A frequently asked question is: should one exert first compression or defibrillation when delivering care in a cardiac arrest by ventricular fibrillation VF? When a first responder witnesses a cardiac arrest in an adult and an AED is available, the first responder should use the equipment first; this recommendation is applied to lay first responders and also to health professionals working in hospitals, or other places where the equipment is available. When more than one first responder is available, one should apply the CPR maneuvers until the AED arrives. The ideal is for one of them to keep up the maneuvers until the other turns on the automated defibrillator ${ }^{(3)}$. When the rescue team gets to the place of an not-witnessed cardiac arrest out of the hospital, it is reasonable to apply the five CPR cycles (around two minutes) before verifying the rhythm and trying defibrillation. However, in case the interval between the emergency call and the response is longer than four or five minutes, the physician in command should consider the possibility of introducing a protocol that allows the first responder to apply five cycles or two minutes of CPR, before trying defibrillation ${ }^{(3-5,7)}$.

These changes aim to simplify and emphasize the maneuvers of basic life support as essential strategies in the improvement of survival after a

\section{REFERENCES}

1 Lane JC. Novas diretrizes de reanimação cardiorrespiratória cerebral da Sociedade Americana de Cardiologia (20052006). Arq Brás Cardiol 2007; 89(2): e17-e18.

2 Capovilla B.C. Ressuscitação cárdio-respiratória: uma análise do processo ensino/aprendizagem nas universidades públicas estaduais paulistas. [dissertação]. Campinas (SP): Faculdade de Ciências Médicas, Universidade Estadual de Campinas/UNICAMP; 2002.

3. Currents in emergency cardiovascular care. Highlights of the 2005 american Heart Association Guilelines for Cardiopulmonary Resuscitation and Emergency Cardiovascular Care. Current in Emergency Cardiovascular Care 2005-2006; 16: 1-26.

4. American Heart Association. Guidelines for Cardiopulmonary Resuscitation and Emergency Cardiovascular Care. International Consensus on Science. cardiac arrest. All first responders should perform high quality CPR: they should apply thoracic compressions of adequate depth and number, allow the thorax to draw back after each compression and minimize interruptions of the thoracic compressions.

The most important message of the 2005 guidelines is that a high quality CPR (that is, adequately performed) saves lives, and that all victims of cardiac arrest should receive high quality $\mathrm{CPR}^{(3)}$.

\section{FINAL CONSIDERATIONS}

Given the above, it is observed that the nursing team has the responsibility for the intensive care of the patient in CPA, during CPR and after it, through continuous evaluation, surveillance, and procedures and techniques that complement the medical therapy based on nursing care guidelines, assuring the continuity of an integrated work, counseling and welcoming family members ${ }^{(8)}$.

Nurses should adopt styles of participative leadership, share and/or delegate functions as part of the organization of this environment prepared to care for the victim in CPA. The main abilities for the management of nursing care are communication and interpersonal relationship, leadership, decision making and technical competence ${ }^{(9)}$.

Circulation 2005 January; 112: IV-1-IV-211.

5. International Liaison Committee on Resuscitation.2005. International Consensus on Cardiopulmonary Resuscitation and Emergency Cardiovascular Care Science with Treatment Recommendations. Resuscitation 2005;67:157,341.

6. Bellan M.C. Capacitação do enfermeiro para o atendimento da parada cardiorrespiratória. [Dissertação]. Campinas (SP): Faculdade de Ciências Médicas da Universidade Estadual de Campinas/UNICAMP; 2006.

7. Nolan J. European Resuscitation Council Guidelines for Resuscitation 2005 Section 1. Introduction. Resuscitation 2005; 67: S1, S3, S6.

8. Tacsi YRC, Vendruscolo DMS. A assistência de enfermagem no serviço de emergência pediátrica. Rev. Latino-Am. Enfermagem 2004 Jun; 12(3):477-84.

9. Wehbe G, Galvão C. O enfermeiro de unidade de emergência de hospital privado: algumas considerações. Rev Latino-am Enfermagem 2001 março; 9(2):86-90. 